\title{
Overview of Forecasting Zakat Collection in Indonesia Using Multiplicative Decomposition
}

\author{
Salman Al Parisi \\ IPB Business School
}

\begin{abstract}
Social welfare can be achieved if high economic growth can reduce a country's poverty, accompanied by a decrease in the value of gini coefficient. Zakat is one of the primary instruments of economic philanthropy in Muslim countries, faciliatating redistribution of wealth and income. Zakat potential in Indonesia has reached $R p 286$ trillion, but the actual zakat collection only reached 3.7 trillion in 2015. This study aims to determine the following: (1) the forecasting of zakat collection in Indonesia based on the historical data for the next 5- 10 years or over time and (2) the system used by Muslim countries to collect zakat fund. This study used the multiplicative decomposition forecasting method with annually data collected over 2005-2015. The findings showed that zakat collection would be expected to reach about Rp 5.0 trillion in 2020. It is expected to increase to 8.33 trillion in 2029, with mean absolute percent error (MAPE) value as much as 0.18 . Furthermore, there are different kinds of zakat systems used by Muslim countries. Indonesia uses the voluntary zakat system, which could affect the amount of zakat collection. The findings of this study are expected to inform policy makers regarding the management of zakat collection.
\end{abstract}

Keywords: Forecasting, Zakat Collection, Poverty Eradication, Multiplicative Decomposition

\section{INTRODUCTION}

\section{Background of the Study}

The welfare can be achieved if high economic growth can reduce a country's poverty, accompanied by a decrease in the value of gini coefficient. This notion was supported by Amartya Sen, who said that "development can be seen or perceived as a process of increasing human freedom to be real, so that people can live a more decent and prosperous" (Todaro and Smith, 2012).

If achieving national prosperity is a must, as mandated by the Constitution 1945 and Pancasila point 5, then attempt to realize these objectives become mandatory too. For example, improve the distribution of infrastructure development, the distribution of wealth, and income (wealth does not rotate at a handful of people), as well as equal rights to access public services easily and cheaply. The Central Bureau of Statistics estimates the rate of poverty Indonesia was likely to be high, amounting to $10.86 \%$ (in March 2016) although it did show a downward trend during the previous period, similar to the gini index that remained high too, at 0.397 (in March 2016). Based on a survey of credit, Suisse reported that the $1 \%$ of richest people in Indonesia control as much $49.3 \%$ of national wealth. This was reinforced by the Indonesian poverty severity index, which was reported to be 0.44 . It means that the higher index value, the higher the expenditure inequality among the poor. The most important condition to protect the spirit of society is 
the absence of gaps between the classes of people. The elites and the common people should not be separated from each other until the point of "break up" (Kantarci, 2015).

Poverty is one of the main problems faced by Indonesia. Poverty substance is the lack condition of the resources to fulfill basic needs in the form of clothing, food, shelter, and basic education (Sudibyo, 1995). One instrument that can be used to redistribute wealth and income is zakat. Zakat is one of the primary instruments of economic philanthropy in Muslim countries. Zakat potential in Indonesia has reached Rp 286 trillion in 2015. This amount included potential zakat from various areas, such as zakat in households, private companies, state enterprises, as well as deposits and savings. However, there is still a significant gap between actual and potential zakat fund in Indonesia, because the actual zakat, alms, and sadaqah (ZIS) collection by all zakat institutions in 2015 , which only reached $\mathrm{Rp} 3.7$ trillion, which is less than $1.3 \%$ of its potential (The National Board of Zakat, 2017). Thus, good management is necessary to maximize the zakat fund so as to achieve its potential with the full support of various parties such as Zakat Board, scholars, community leaders, schools, and government agencies.

The important point to estimate the zakat potential collection to improve the management, so the study aims to know (1) the forecasting of zakat fund collection in Indonesia based on the historical data for the next 5 to 10 years or over time and (2) what system is used by Muslim countries to collect zakat fund?

\section{LITERATURE REVIEW}

\section{Definition of Zakat}

Zakat literally has been derived from the Arabic root word that carries the meanings of "that which purifies", as well as "that which fosters", i.e., growth and increase (Siddiqi, 1968). Zakat represents one of the five pillars that constitute Islam. It is a maaliah ijtimaa'iyyah worship with a strategic and decisive position in the improvement of the welfare of the people. Zakat does not only serve as a vertical worship to Allah (hablumminallah), but it also serves as a form of horizontal worship (hablumminannaas) (Hudayati and Tohirin, 2010).

Zakat has been divided into two main items, which are zakat of al-Fitr and also zakat of wealth. Zakat of al-Fitr is the zakat that needs to be paid by Muslims once a year during the month of Ramadan before the Muslim festive season celebration known as Eid Mubarak. Zakat of al-Fitr is also being referred as a zakat of the body. For zakat of wealth, there are a few categories under it, including zakat of business, zakat of saving, zakat of income, zakat of gold and silver, zakat of poultry (for instance like cow, goat and so on), zakat of fruits and grain, zakat of entrenchment, zakat of investment as well as zakat of employees provident fund (EPF) saving. There are eight groups of people qualified to receive zakat, as mentioned by Allah in His Holy Quran (QS: At-Taubah: 60), including al-Fuqara' (needy/strained), al-Masakin (poor/deficient/lacking), amil (has right to collect zakat), mualaf (convert/reconciled to Islam), al-Riqab (slave), al-Gharimin (people in debt), fi-sabililLah (Allah's cause), and Ibn as-Sabil (traveler/wayfarer) (Lubis et al, 2011).

\section{Time Series Data}

Time series is a set of observations built sequentially in time. The time or period required to perform a forecasting is usually referred to as the lead times, which vary at each issue.

Time series is a series of observations taken by the order and adjacent observations are correlated, so it 
is said that in the time series, each observation is taken from a variable correlated with the variable itself at an earlier time (Wei, 2006).

In forecasting, the value of a variable in the future must be considered and studied depending on the nature and development of the variables in the past. The value of variables can be predicted if the current and past values of the variables are known and the historical development of a variable can be evalulated and the order of values can be observed over time. This is called the time sequence of the time series; in other words, the time series is a series of observations of an event, where the occurrence, symptoms, or variables are recorded accurately in a periodic manner by the sequence of events and then compiled as data. The frequency of recording can be weekly, monthly, annually, etc.

Makridakis et al. (1999) showed that an important step in choosing an appropriate method of developing a time series is to consider the type of data patterns, so that the most appropriate method for the data pattern can be determined. The data pattern can be divided into four, namely (1) a horizontal pattern, it happens when data values fluctuate around a constant mean value; (2) the seasonal pattern, it occurs when a series is affected by seasonal factors (e.g., a particular quarterly, monthly, or days in a particular week); (3) the cyclical pattern, which occurs when the data is influenced by fluctuations in the long-term economy as it relates to the business cycle, for example in sales of products such as automobiles, steel, and others, (4), the pattern of trend, which occurs when there is an increase or decrease of a long-term secular in the data.

\section{Forecasting Concept}

Forecasting is estimation of what will happen in the future, while plan is determining what to do in the future
(Subagyo, 1986). To make a long-term plan, a company should consider the capacity, price elasticity, forecast customer demand, and so on.

According to Supranto (1984), forecasting is the making of assumptions regarding the occurrence of events in the future. Forecasting is to estimate something at those times that will come in the past based on the data analyzed scientifically, particularly using statistical methods. Forecasting is the art and a science of predicting events that might be encountered in the future.

Forecasting is a science to predict conditions or events that would occur with the use of historical data and project it into the future with some form of mathematical models. Two main aspects that must be considered in the forecasting process are accuracy and usefulness; in other words, using relevant data and appropriate forecasting techniques. Forecasting can be performed via various methods, and the choice of the method depends on the data and information that will be predictable and the objectives to be achieved (Makridakis et al, 1999).

In practice, there are various quantitative forecasting methods. First, Moving Averages either "simple" or "weighted." Second, exponential smoothing is the method of forecasting by adding parameter (alpha) in the model to reduce the randomness of the factor. Third is trend projection. Trend projection with regression method is a method that is used both for the short term and long term. This method is a trend line for mathematical equations. In addition, there are other forecasting methods such as decomposition, ARIMA, and other forecasting methods.

In social life, everything is uncertain and regular estimations are difficult. Therefore, forecast is necessary. Forecasting is necessary to (1) minimize the effect of uncertainty, (2). forecasting aims to minimize forecast error, which measured by the mean squared error 
(MSE), mean absolute percent error (MAPE), and others (Subagyo, 1986).

\section{Previous Study}

Some studies have been published on zakat with a wide variety of methodologies. Previous studies have shown that there are three researches about forecasting zakat collection. However, forecasting research can help policy makers determine the extent of zakat potential can be achieved in the long term and as an evaluation of what should be done so that the total zakat potential can be achieved. Below is a summary of the zakat research as follows:

Table 2.1. The Previous Study

\begin{tabular}{|c|c|}
\hline Name/ Year/ Title & Method \& Result \\
\hline Parisi (2017) & DEA and Malmquist Productivity Index \\
\hline \multirow[t]{2}{*}{$\begin{array}{l}\text { Efficiency and } \\
\text { Productivity of Zakat } \\
\text { Institutions in } \\
\text { Indonesia }\end{array}$} & $\begin{array}{l}\text { There are } 5 \text { DMUs that perfectly efficient (constant return to scale). Ten } \\
\text { DMUs are classified to the increasing return to scale. Twelve DMUs are } \\
\text { classified to decreasing return to scale. Furthermore, the lowest relative } \\
\text { efficiencies level is DD (2010), amounting to } 9.63 \% \text {. }\end{array}$ \\
\hline & $\begin{array}{l}\text { In addition, approximately } 80 \% \text { of five OPZs increased the productivity. } \\
\text { In general, the main factor of inefficient of five zakat institutions from } \\
2005 \text { to } 2014 \text { was caused by the distribution of zakat to ashnaf, which is } \\
\text { still not optimal, since it cannot solve the poverty rate. Furthermore, it } \\
\text { needs to increase collection and distribution of zakat fund amounted to } \\
31.53 \% \text { and } 47.87 \% \text {. Further, it needs to decrease the cost of socialization } \\
\text { and operational cost amounted to } 11.81 \% \text { and } 8.79 \% \text {. }\end{array}$ \\
\hline \multirow{5}{*}{$\begin{array}{l}\text { Akbarizan, Marizal, } \\
\text { Soleh, Hertina, Abdi, } \\
\text { Yendra, Fudholi (2016) } \\
\text { Utilization of Holt's } \\
\text { Forecasting Model for } \\
\text { Zakat Collection in } \\
\text { Indonesia }\end{array}$} & Holt's exponential smoothing and ARIMA model \\
\hline & $\begin{array}{l}\text { Results show that Holt's exponential smoothing best fits the zakat time } \\
\text { series data and is therefore suitable for forecasting zakat. Holt's }\end{array}$ \\
\hline & exponential smoothing is comparable to the ARIMA model, given its \\
\hline & small deviations in mean absolute percentage error and mean square error. \\
\hline & $\begin{array}{l}\text { Moreover, the sottware used to implement Holt } s \text { exponential smoothing } \\
\text { is similar to that used in ARIMA models. These similarities show that } \\
\text { these models can accurately forecast future trends to prepare proper } \\
\text { strategies and plan the future of the organization. These models can also } \\
\text { be used to develop a plan for managing charity based on the number of } \\
\text { recorded mustahiq. }\end{array}$ \\
\hline \multirow{3}{*}{$\begin{array}{l}\text { Hamzah and Krishnan } \\
\text { (2016) } \\
\text { Measuring the } \\
\text { Efficiency of zakat } \\
\text { collection process } \\
\text { using DEA }\end{array}$} & DEA-CCR Model \\
\hline & $\begin{array}{l}\text { The results revealed that the collection process was efficient in } 2009 \text { and } \\
2012 \text {, with their respective efficiency scores equaling to one. However, } \\
\text { further analysis revealed that } 2009 \text { had actually prevailed } 2012 \text { in the } \\
\text { context of collection efficiency as } 2009 \text { was benchmarked more } \\
\text { frequently than 2012, against the inefficient years. }\end{array}$ \\
\hline & $\begin{array}{l}\text { The other seven years were found to be inefficient since there were } \\
\text { discrepancies between the amount of input (i.e., number of branches and } \\
\text { staff) used and amount of output (i.e., total collections) produced. In } \\
\text { addition, by further investigating the actual causes of inefficiency in each } \\
\text { affected year, it was concluded that the main cause of inefficiency was } \\
\text { due to excessive usage of staff for the collections that had been made. In } \\
\text { other words, to sidestep the similar undesirable situation in the future, the }\end{array}$ \\
\hline
\end{tabular}




\begin{tabular}{|c|c|}
\hline & $\begin{array}{l}\text { management should consider using minimum possible staff for the } \\
\text { purpose of collecting zakat or completely utilize the available staff to } \\
\text { maximize the total collections. } \\
\text { A more detailed research could be conducted in future where the } \\
\text { efficiency in collection process is not only evaluated based a specific } \\
\text { interval of time but also based on different branches where the result } \\
\text { could be helpful in diverting the management's primary attention on the } \\
\text { most underperforming branches. Further, future research could expand } \\
\text { this study by applying a two-stage DEA model to compare the } \\
\text { performance of Pusat Zakat Sabah in the context of both collection as } \\
\text { well as distribution efficiency as to provide better hints to the } \\
\text { management concerning the operation towards which major attention } \\
\text { should be allocated for further refinement. }\end{array}$ \\
\hline Ibrahim (2015) & Qualitative Method \\
\hline $\begin{array}{l}\text { The Role of Zakat in } \\
\text { Establishing Social } \\
\text { Welfare and Economic } \\
\text { Sustainability }\end{array}$ & $\begin{array}{l}\text { This study suggests that zakat should be institutionalized and properly } \\
\text { managed by the Islamic states and various Muslim communities. The use } \\
\text { of charity organizations will be helpful in places where there is no Islamic } \\
\text { state. Similarly, local zakat committees should be constituted at the lower } \\
\text { level; all zakat activities is to be overseen by the shariah committees who } \\
\text { to be responsible for ensuring shariah compliance and avoidance of any } \\
\text { misapplications. This use of electronic and print media, Muslim scholars } \\
\text { and Khateebs (religious scholars) may join hands to create awareness } \\
\text { among people about the importance of zakat and its social, moral, } \\
\text { economic and spiritual impact on the society. }\end{array}$ \\
\hline $\begin{array}{l}\text { Johari, Ali, and Aziz } \\
\text { (2015) }\end{array}$ & Regression Analysis, Primary Data. \\
\hline $\begin{array}{l}\text { The Role of Zakat } \\
\text { Distribution Among } \\
\text { Muallaf (New Convert) } \\
\text { in Reducing Poverty in } \\
\text { Selangor, Malaysia }\end{array}$ & $\begin{array}{l}\text { Results indicate that only family size, gender (male), income, and } \\
\text { expenditure variables have a significant effect on zakat distribution, while } \\
\text { age, status, race, previous religion, highest education, job, and region } \\
\text { variables did not have any significant effect on zakat distribution among } \\
\text { the new converts. Thus, zakat distribution is significant in reducing } \\
\text { poverty burden among the new converts by increasing their income and } \\
\text { positively improves their budget for expenditure. Thus, these statistical } \\
\text { measures have proven a positive role of zakat in reducing poverty among } \\
\text { the new converts. However, for zakat distribution to have significant } \\
\text { impact on the quality of life among the new converts, immediate actions } \\
\text { need to be taken to ensure that at least their needs are satisfied and } \\
\text { adequate. }\end{array}$ \\
\hline Anonymous (2015) & Panel Data Regression \\
\hline $\begin{array}{l}\text { The Impact of Zakat on } \\
\text { Income Inequality and } \\
\text { Poverty in Malaysia; A } \\
\text { Panel Data Analysis }\end{array}$ & $\begin{array}{l}\text { The results indicated that while zakat has no significant effect on income } \\
\text { inequality, zakat significantly reduced both poverty incidence and } \\
\text { hardcore poverty. The study suggested zakat institutions funds } \\
\text { distribution should follow the Had-Kifayah Zakat distribution model. }\end{array}$ \\
\hline $\begin{array}{l}\text { Ahmad and Ma'in } \\
\text { (2014) }\end{array}$ & \\
\hline $\begin{array}{l}\text { The Efficiency of } \\
\text { Zakat Collection and } \\
\text { Distribution: Evidence } \\
\text { from Two Stage } \\
\text { Analysis }\end{array}$ & $\begin{array}{l}\text { The results indicated that while zakat has no signifi cant effect on income } \\
\text { inequality, it significantly reduced both poverty incidence and hardcore } \\
\text { poverty. The study suggested Zakat institution funds should employ Had- } \\
\text { Kifayah Zakat distributi on model. }\end{array}$ \\
\hline
\end{tabular}




\begin{tabular}{|c|c|}
\hline Duka (2013) & Qualitative research methods with a phenomenological approach \\
\hline $\begin{array}{l}\text { The Role of } \\
\text { Government in } \\
\text { Optimizing of 'Zakat' } \\
\text { Management at } \\
\text { Mamuju District } \\
\text { Province West }\end{array}$ & $\begin{array}{l}\text { The role of government has an important impact on the strengthening of } \\
\text { institutional zakat (Bazda) in the management of zakat in Mamuju. BAZ } \\
\text { institutional strength, in addition to the legal support of the legislation, } \\
\text { declaration, and political support from the Regent, is also due to the } \\
\text { increasing public confidence. Public trust arises as a result of the } \\
\text { implementation of the management system of public accountability. }\end{array}$ \\
\hline Sulawesi & $\begin{array}{l}\text { Indicators of institutional strengthening and public confidence can be seen } \\
\text { from the zakat fund revenue increase from } 2009 \text { to 2012, and the } \\
\text { increasing number of muzakki who gave zakat to Bazda. }\end{array}$ \\
\hline $\begin{array}{l}\text { Razak, Ismail, } \\
\text { Hamzah, Hashim } \\
\text { (2013) }\end{array}$ & $\begin{array}{l}\text { Ms. Excel Trend Line, for polynomial, exponential and Malthusian } \\
\text { model }\end{array}$ \\
\hline Overview of Zakat & $\begin{array}{l}\text { As a result, Malthusian is the best model to be use since it has the } \\
\text { smallest amount of SSE compared to the other two models. }\end{array}$ \\
\hline $\begin{array}{l}\text { Collection in Malaysia; } \\
\text { Regional Analysis }\end{array}$ & $\begin{array}{l}\text { It shows that the value and the model is more accurate to forecast the } \\
\text { future trends in order to prepare proper strategies and the future planning } \\
\text { for the organization. }\end{array}$ \\
\hline Ubaidillah and & Artificial Neural Network \\
\hline & Based on the results in this study, we can conclude that ANN model with \\
\hline $\begin{array}{l}\text { Forecasting Zakat } \\
\text { Collection Using } \\
\text { Artificial Neural } \\
\text { Network }\end{array}$ & $\begin{array}{l}\text { BP learning algorithm is recommended as the model to forecast the zakat } \\
\text { collection. Since accurate forecasting can help to improve the } \\
\text { management of zakat centre, research on how to obtain more accurate } \\
\text { forecasting model should be done by hybridizing ANN model with other } \\
\text { models such ARIMA, regression, and SVM. }\end{array}$ \\
\hline
\end{tabular}

\section{RESEARCH METHODOLOGY}

\section{Types and Sources of Data}

This study is about forecasting models. The data used in this research are secondary data such as time series data of the zakat fund collection during 20052015. Secondary data were obtained from the Center of Strategic Studies, the National Board of Zakat report. The analysis tools were POM-QMv3 (Quantitative Method) software and MS Excel.

\section{Quantitative Forecasting Methods}

Quantitative forecasting methods can be divided into two types, namely causal and time series. Causal forecasting methods include factors related to the predicted variables such as regression analysis, while time series forecasting method is a quantitative method for analyzing the data of the past that has been collected regularly by the right technique. The results can be used as a reference for forecasting in the future (Makridakis et al, 1999).

The quantitative forecasting method is to use predict an event by using historical data, regardless of the influence or relationship with other variables. The forecasting method used is quantitative statistical analysis to evaluate the pattern of data changes over time (Makridakis and Wheelwright, 2010). Quantitative forecasting can also be applied in the presence of any of the following conditions (Martiningtyas, 2004): (1) information available about the past, (2) information can be quantified in the form of numerical data, (3) some aspects of past patterns can be assumed to continue in the future. Furthermore, there are several statistical quantitative forecasting methods (Makridakis and Wheelwright, 2010): (1). 
method of moving averages. Forecasting is performed by collecting a group of observed values, determining the average, and then using this average as a forecast for the next period. There are two types of moving average method, namely singleand double-moving average as well as (2) Exponential smoothing is classified into three types, namely single exponential smoothing, double exponential smoothing, and triple exponential smoothing. (3). The decomposition method is based on events that occur and will repeat with the same pattern. Decomposition method has four major components of the pattern of change, i.e., trend ( $\mathrm{T})$, seasonal fluctuation (M), cyclic fluctuation (S), and random change (R).

\section{Multiplicative Decomposition}

One way to analyze the time-series data is to perform decomposition for the purpose of identifying the components that affect the data. Four time-series components commonly studied are (1) trends, (2) cyclical, (3) seasonal, and (4) stationary/ Horizontal. In decomposition, the mathematical model of a long-term time series (annual) can be regarded as the multiplication from both the trend fluctuation and cyclical fluctuation components.

Where:

$$
X=\operatorname{Tx} C
$$

$\mathrm{X}$ is the actual value

$\mathrm{T}$ is the trends fluctuation

$\mathrm{C}$ is a cyclical fluctuation index

As for short-term time series data (less than 1 year), the mathematical model is a product of four components:

$$
X=T C S H
$$

$\mathrm{S}$ is the seasonal fluctuations

$\mathrm{H}$ is the horizontal fluctuation (stationary)
Decomposition analysis is used to analyze the data contained in the seasonal pattern and generate the forecast a long period ahead. This analysis has two models:

1. Additive

2. Multiplicative.

The additive model is used to measure the seasonal pattern, which is not proportional to the data (no pattern widened or narrowed but constant); a straight line is achieved by adding the seasonal form, while the multiplicative model has proportional seasonal pattern size with data (there is a wide pattern or shrink).

Additive decomposition calculates the time series decomposition on the components of the trend, seasonal, cyclical, and error. This method identifies the future forecast and sum of the projections of the forecasting results. The model assumed to be additive (all components are added to obtain the results of the forecast). The model equations are:

$$
X^{\prime}{ }_{t}=T_{t}+S_{t}+C_{t}+\varepsilon_{t}
$$

where $\mathrm{T}$ is the trend, $\mathrm{S}$ is a seasonal component, $\mathrm{C}$ component is cyclic, and $\varepsilon$ is the error.

Multiplicative decomposition calculates the time-series decomposition on the components of the trend, seasonal, cyclical, and error. This method identifies future forecast. The model assumed to be multiplicative (all components are multiplied by each other to get the forecasting models). Model equations are as follows:

$$
\mathbf{X}_{\mathbf{t}}^{\prime}=\mathbf{T}_{\mathbf{t}} * \mathbf{S}_{\mathbf{t}} * \mathbf{C}_{\mathrm{t}} * \mathbf{E}_{\mathrm{t}}
$$

where $\mathrm{T}$ is the trend, $\mathrm{S}$ is a seasonal component, $\mathrm{C}$ component is cyclic, and $\varepsilon$ is the error. 
Exponential Smoothing with Trend

Exponential smoothing with trend is another kind of exponential smoothing that is used when a time series shows a linear trend. The pattern of exponential smoothing with trend is expressed as follows (Heizer and Render, 2009):

$$
\begin{gathered}
F_{t}=\mathrm{F}_{\mathrm{t}}+\mathrm{T}_{\mathrm{t}} \\
F_{t}=\alpha\left(A_{t-1}\right)+(1-\alpha)\left(\mathrm{F}_{\mathrm{t}-1}+\mathrm{T}_{\mathrm{t}-1}\right) \\
T_{t}=\beta\left(F_{t}-F_{t-1}\right)+(1-\beta) T_{t-1}
\end{gathered}
$$

Information:

$\mathrm{Ft}=$ forecasting by exponential smoothing from the data series in period $t$,

$\mathrm{Tt}=$ trend with exponential smoothed in period $t$,

At $=$ actual demand in period $t$,

$\mathrm{a}=$ constant of smoothing for average $(0 \leq$

$\alpha \leq 1)$,

$\beta=$ constant of smoothing for trend $(0 \leq \beta$ $\leq 1)$.

\section{Trend Analysis (Regress over time)}

Trend analysis is a time series forecasting method in accordance with the trend line to a series of data in the past, which is then projected into the future forecasting. The formula of trend analysis is as follows (Heizer and Render, 2009):

$$
\begin{gathered}
(y=a+b x) \\
a=\frac{\sum y}{n} \\
b=\frac{\sum x y}{x^{2}}
\end{gathered}
$$

Information:

$\mathrm{Y}=$ Dependent variable

$\mathrm{X}=$ Independent variable (time)

$\mathrm{a}=$ Constant

$\mathrm{b}=$ coefficient Trend

$\mathrm{n}=$ number of data (observations)

\section{RESULT AND DISCUSSION}

\section{The Forecasting of Zakat Collection}

Forecasting involves the processing of information systematically to estimate of future occurrences based on past information and the present time, so the mistakes can be minimized (Riduwan, 2010). In general, the steps of the forecasting method are to collect data, to select data, to choose the forecasting model, to use the chosen model for forecasting, and then finally evaluate the final result.

This study uses quantitative methods with the time-series approach. The time series method is a forecasting method that using pattern analysis of the relationship between variables to be predicted by the time variable (time series analysis). The methods chosen for analysis are the standard (moderate) prediction that using exponential smooting with trend $(0.5$ Alpha, Betha 0.5), then the optimistic prediction that uses exponential smooting with trend (alpha, 0.7; beta, 0.7), and the pessimistic prediction that uses trend analysis.

This study aims to predict the collection of zakat fund in Indonesia for the next year. Discussion about potential of zakat collection in Indonesia has always been a topic of particular interest for the stakeholders of Islamic economics. This is caused by the persistence of a large gap between actual zakat funds collection and the zakat potential in Indonesia. According to BAZNAS, in 2015, the zakat potential reached $\mathrm{Rp} 286$ trillion, while the actual zakat fund collection only reached $\mathrm{Rp} 3.7$ trillion. In other words, zakat fund collection was only reached less than $1.3 \%$ of its potential in 2015 (The National Board of Zakat, 2017).

There are three schemes of forecasting calculation: pessimistic, moderate, and optimistic approaches. Data used in this analysis were annual data collected for the period 2005 to 2015 . 
Firstly, pessimistic prediction uses trend analysis. Gaph 4.1 describes the forecasting of zakat funds collection, which can reach up to $\mathrm{Rp} 3.75$ trillion until the end of 2016 with mean absolute percent error (MAPE) of 0.19. It means that the forecasting of zakat fund collection is still very small compared with to its potential. However, there was an increase of zakat collection compared to that in the previous year.

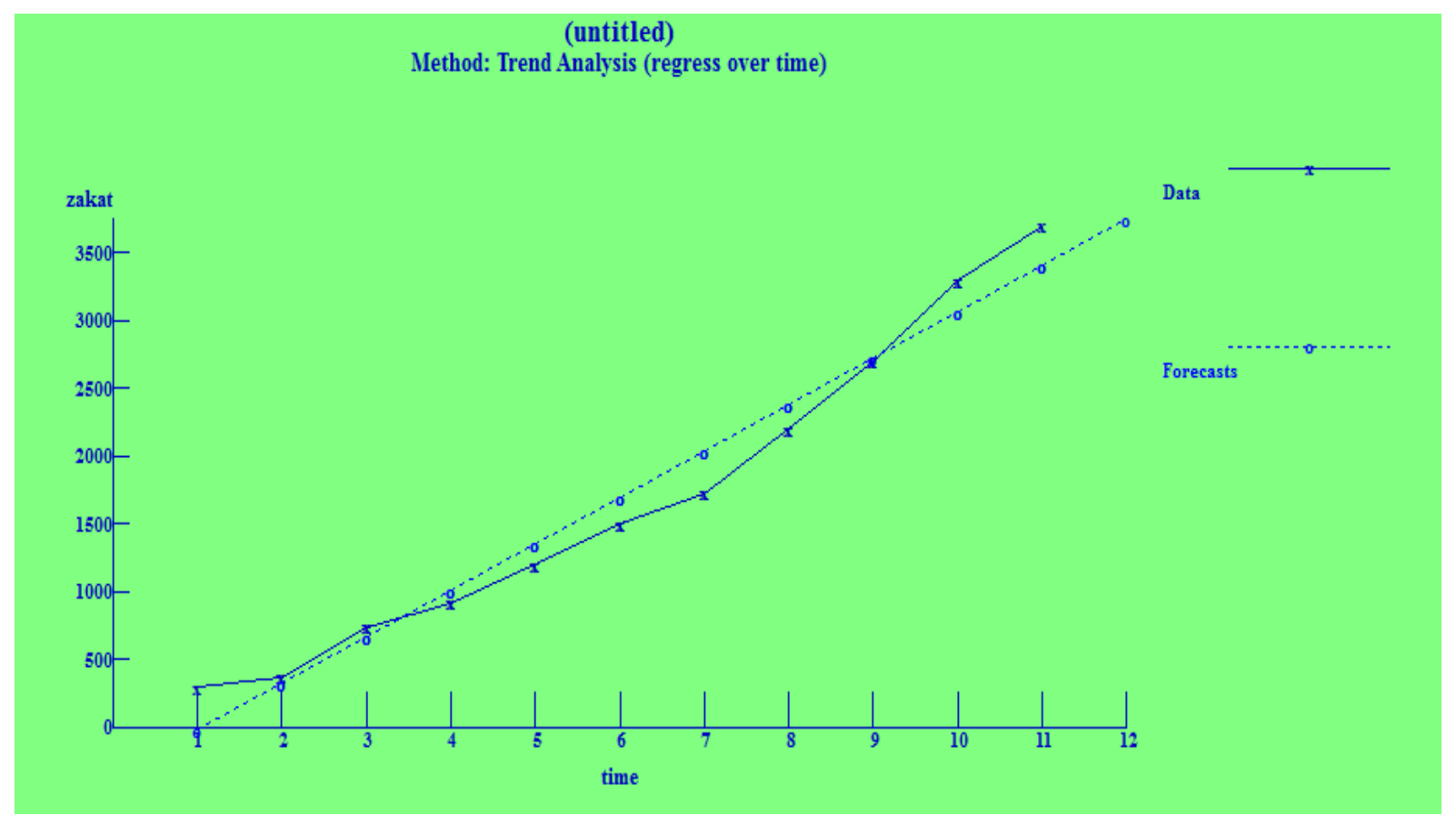

Figure 4.1. Forecasting of Zakat Collection with Trend Analysis Approach (Pessimistic)

Second is moderate prediction. This scheme uses exponential smooting with trend and is also based on the alpha value, which gives the smallest error rate by providing the value of mean square error (MSE), with alpha 0.5 and beta 0.5 . From the graph 4.2 below, it can be seen that the overall collection of zakat has increased from year to year. Based on data from BAZNAS, zakat fund collection reached 68.39 billion in 2002 and increased to 3.7 trillion in 2015. However, the number of zakat funds in 2015 amounted to 3.7 trillion, which still shows a large gap with its potential in Indonesia. As per the moderate scheme discussed above, the forecasting of zakat funds can be collected up to the end of 2016 was around $\mathrm{Rp} 4.16$ trillion with MAPE value as much as 0.16 . Thus, there was an increase of zakat collection from previous year. The description of zakat fund estimation in 2016 showed that the existance of a large gap between actual zakat fund collection and zakat potential in Indonesia. 


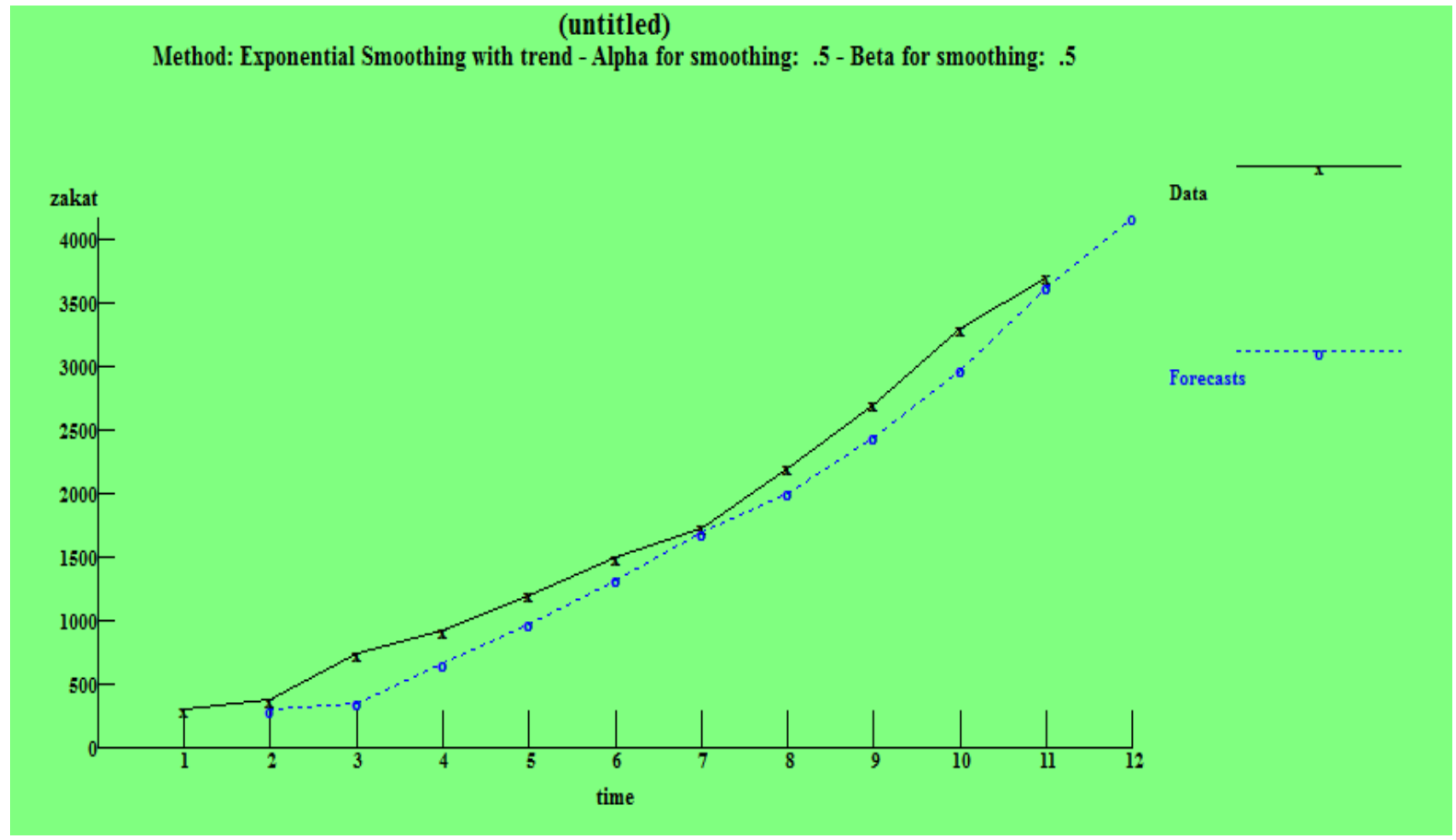

Figure 4.2. Forecasting of Zakat Collection by Exponential Smoothing with Trend (Moderate)

Thirdly, the optimistic prediction. This scheme uses exponential smoothing with the trend approach (alpha, 0.7; beta, 0.7 ). Graph 4.3 below showed that the forecasting of zakat funds collection in
2016 was around $\mathrm{Rp} 4.24$ trillion with MAPE value of 0.11 . This is expected to be realized. However, the result is still not optimal, if it is compared with its potential.

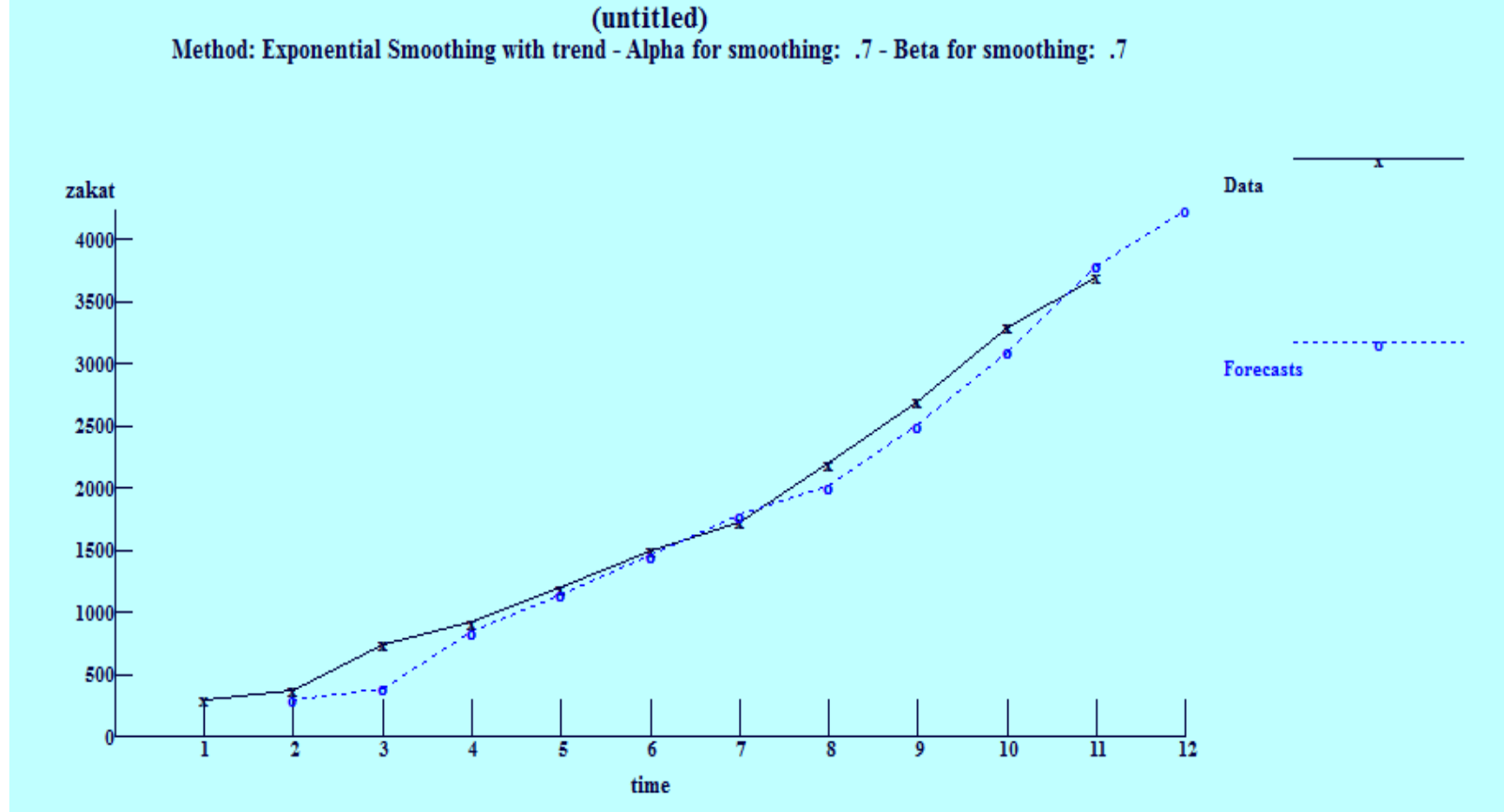

Figure 4.3. Forecasting of Zakat Collection by Exponential Smoothing with Trend (Optimistic)

Fourthly, this study predicts the total zakat funds could be collected during the next 5 to 10 years or over time. This study uses the multiplicative 
decomposition approach. The forecasting of zakat collection has reached about Rp 5.0 trillion in 2020 and it is expected to increase to 8.33 trillion in 2029 with MAPE value as much as 0.18 . Forecasting of this study is an organic calculation, which assumes no extraordinary effort from government and stakeholders of zakat in the national development strategies. Therefore, it still has large gap with its potential. Thus, we have to solve this problem with good management.

Table 4.1. Forecasting of Zakat Collection with Multiplicative Decomposition Approach

\begin{tabular}{|l|r|r|r|r|r|}
\hline Measure & Value & $\begin{array}{r}\text { Future } \\
\text { Period }\end{array}$ & $\begin{array}{r}\text { Unadjusted } \\
\text { Forecast }\end{array}$ & $\begin{array}{r}\text { Seasonal } \\
\text { Factor }\end{array}$ & $\begin{array}{r}\text { Adjusted } \\
\text { Forecast }\end{array}$ \\
\hline Error Measures & & 12 & 3793.45 & .97 & 3668.51 \\
\hline Bias (Mean Error) & .03 & 13 & 4139.51 & 1 & 4160.45 \\
\hline MAD (Mean Absolute Deviation) & 173.37 & 14 & 4485.57 & .97 & 4337.84 \\
\hline MSE (Mean Squared Error) & 40910.22 & 15 & 4831.63 & 1 & 4856.08 \\
\hline Standard Error (denom=n-2-2=7) & 253.55 & 16 & 5177.69 & .97 & 5007.17 \\
\hline MAPE (Mean Absolute Percent Error) & .18 & 17 & 5523.75 & 1 & 5551.7 \\
\hline Regression line (unadjusted forecast) & & 18 & 5869.81 & .97 & 5676.49 \\
\hline zakat =-359.2769 & & 19 & 6215.87 & 1 & 6247.32 \\
\hline +346.06 * time & & 20 & 6561.93 & .97 & 6345.82 \\
\hline Statistics & & 21 & 6908 & 1 & 6942.94 \\
\hline Correlation coefficient & .98 & 22 & 7254.05 & .97 & 7015.15 \\
\hline Coefficient of determination $\left(r^{\wedge}\right.$ 2) & .97 & 23 & 7600.11 & 1 & 7638.57 \\
\hline & & 24 & 7946.17 & .97 & 7684.47 \\
\hline & & 25 & 8292.23 & 1 & 8334.19 \\
\hline
\end{tabular}

Source: Zakat Collection 2005-2015

Center of Strategic Studies, the National Board of Zakat (2017)

According to Saidi (2008), zakat is a source of economic funds for financing of the state economy. It can be a solution to alleviate poverty. Politically, the state has an important role in fulfilling the clothing, food, and housing needs to the people. This role is a fundamental policy in an Islamic economy, and zakat has a role to distribute the wealth based on fairness. Allah says in the Qur'an Al-Hashr verse 7: So that the treasure was not circulated among the wealthy of you. From the explanation above, we can know about the importance of wealth distribution, because it can circulate the wealth among people. Therefore, it can increase the purchasing power of society, and finally, the poverty rate will decrease gradually (ceteris paribus).
The poverty rate of Indonesia is still relatively high at $10.86 \%$ in 2016 . In addition, the gini coefficient reached 0.397 in 2016 (BPS: 2017). Thus, the management of zakat funds has not been distributed optimally so that its benefits cannot be perceived by the public as a whole. Ultimately, it affects the level of public trust in zakat institutions. In fact, zakat funds managed by the institution have more significant influence than zakat fund given by muzaki to mustahik directly. Because, if zakat fund is managed by the institutions, then it will be divided into productive zakat and consumptive zakat. Then, the conclusion is that there is a big problem in management of the zakat fund collection.

The forecasting of zakat collection above can be a general overview for the 
zakat institution and the stakeholders. There are some factors that can affect the level of zakat fund collection. According to Mubarok and Fanani (2014), there are factors that affect the zakat fund collection in Indonesia such as the quality of financial reporting, lack of people's trust in the zakat institution where their zakat fund is channeled, absence of an accurate database of mustahik maintained by zakat institutions, and lack of understanding about the obligation of zakah and its percentage among many Muslims. Another reason is the weak institutional framework and weak implementation of the rules of zakat since there is no punishment for those who do not pay zakat, whereby the efficiency and effectiveness of the innovative utilization of zakat funds remains low.

Lack of public awareness regarding the payment of zakat is one of the main reasons for zakat being the most neglected obligation in Indonesia, whereas, Allah condemned the prayer that does not bear the social piety (Q.S. Al-Maun: 7). In the Qur'an Al Maun verse 7, it is mentioned that "it will harm people who are not willing to provide assistance". Some of mufassir interpret it with people who do not want to pay zakat or lend household appliances. Zakat is as an important instrument to solve social inequality, and it should be able to solve the problems of the poverty rate of the country, especially in Indonesia. Zakat is as a manifestation of social piety that was implemented by the Islamic government of Umar bin Abdul Aziz.

Then, the government must have the political will to strengthen the laws regarding the institutional management of zakat, with an objective of enhancing the awareness of Muslim in paying zakat. Besides this, the zakat institutions have to increase the management process. The payment of zakat is made difficult by some issues that need much attention such as lack of satisfaction among zakat payers regarding its management. Because good management will increase the trust among zakat payers (muzaki), a big concern is the collection of the zakat potential in Indonesia, which would allow optimal distribution of zakat funds to zakat recipients (mustahik), so that the benefits can be experienced by the public.

\section{The Pattern of Zakat Collection System in Muslim Countries}

Every country has a regulation to run the system. Zakat systems followong in Muslim countries are as follows:

Table 4.2. Zakat System in Muslim Countries

\begin{tabular}{|l|l|l|l|}
\hline \multicolumn{1}{|c|}{ Country } & \multicolumn{1}{|c|}{ Approach to zakat } & \multicolumn{1}{c|}{ Country } & \multicolumn{1}{c|}{ Approach to zakat } \\
\hline Afghanistan & No government system & Morocco & No government system \\
\hline Algeria & No government system & Niger & No government system \\
\hline Azerbaijan & No government system & Nigeria & No government system \\
\hline Bahrain & Voluntary & Oman & No government system \\
\hline Bangladesh & Voluntary & Pakistan & Mandatory \\
\hline Burkina Faso & No government system & Qatar & No government system \\
\hline Chad & No government system & Saudi Arabia & Mandatory \\
\hline Egypt & Voluntary & Senegal & No government system \\
\hline Guinea & No government system & Sierra Leone & No government system \\
\hline Indonesia & Voluntary & Somalia & No government system \\
\hline Iran & Voluntary & Sudan & Mandatory \\
\hline Iraq & No government system & Syria & No government system \\
\hline Jordan & Voluntary & Tajikstan & No government system \\
\hline Kazakhstan & No government system & The Gambia & No government system \\
\hline Kuwait & Voluntary & Tunisia & No government system \\
\hline Lebanon & Voluntary & Turkey & No government system \\
\hline Libya & Mandatory & Turkmenistan & No government system \\
\hline Malaysia & Mandatory & U.A.E. & Voluntary \\
\hline Mali & No government system & Uzbekistan & No government system \\
\hline Mauritania & No government system & Yemen & Mandatory \\
\hline
\end{tabular}

Source: Moneyjihad Website (2017) 
Zakat system used by each country could affect the collection of zakat in the country. Indonesia is a country that uses a voluntary approach for zakat funds collection. This is in line with UU No. 23 of 2011 and PP. No. 14 of 2014 about the Zakat Management; there is no law about sanction for muzaki who do not pay zakat, to improve the zakat collection. Malaysia, on the other hand, uses a mandatory system, which followed by zakat socialization and zakat payment as a tax deduction. It can increase the zakat collection. According to Shirazi and Amin (2009), Malaysia requires a small amount of resources to eliminate poverty to about $0.02 \%$ of GDP. Furthermore, Yaumidin (2009) estimates that the resources needed for poverty alleviation and zakat potential collection for Malaysia and Indonesia. Then, she concludes that Malaysia performs better than Indonesia.

\section{CONCLUSION}

There is still a large gap between the actual zakat collection and its potential. A forecast of zakat collection in the next period is necessary for evaluating the management. Firstly, based on pessimistic prediction, forecasting of zakat funds collection showed that the values could reach up to $\mathrm{Rp} 3.75$ trillion until the end of 2016. Secondly, based on moderate prediction, it was mentioned that the forecast of zakat funds that can be collected up to the end of 2016 was around Rp 4.16 trillion. Thirdly, the optimistic prediction, the forecasting of zakat funds collection in 2016 was around $\mathrm{Rp} 4.24$ trillion. Fourthly, using the multiplicative decomposition approach, the zakat collection can reach up to about Rp 5.0 trillion in 2020. It is expected to increase to 8.33 trillion in 2029 . Forecasting of this study is an organic calculation, which assumes no extraordinary effort from government and stakeholder of zakat in the national development strategies.
Therefore, there is still has large gap with its potential. Thus, we have to solve this problem with the good management, big effort, and full support from all of parties such as zakat board, scholars, schools, and government.

Furthermore, the zakat system used in each country could affect the collection of zakat in the country. Indonesia is a country that uses a voluntary approach in zakat funds collection. This is in line with UU No. 23 of 2011 and PP. No. 14 of 2014 about zakat Management; there is also no provision about sanction for muzaki who do not pay zakat. This contributes to the lack of optimal zakat collection, which still far from its potential.

\section{REFERENCES}

Ahmad, Ismail. HJ \& Ma'in, Masturah. (2014). "The Efficiency of Zakat Collection and Distribution: Evidence from Two Stage Analysis", Journal of Economic Cooperation and Development, 35(5), pp. 133170.

Akbarizan; Marizal, Muhammad; Soleh, M; Hertina; A, Mohammad A; Yendra, R \& Fudholi, A. (2016). "Utilization of Holt's Forecasting Model for Zakat Collection in Indonesia", American Journal of Applied Sciences, 13(12), pp. 13421346.

Anonymous. (2015). “The Impact of Zakat on Income Inequality and Poverty in Malaysia; a Panel Data Analysis", Market Forces College of Management Sciences, 10(1).

Duka, Suhardi. (2013). "The Role of Government in Optimizing of 'Zakat' Management at Mamuju District Province West Sulawesi", Journal of Economics and Sustainable Development, 4(18), pp. 134-140. 
Hamzah, Ahmad. A \& Krishnan, Anath. R. (2016). "Measuring the Efficiency of Zakat Collection Process Using DEA", The 4th International Conference on Quantitative Sciences and Its Applications (ICOQSIA 2016), Published by AIP Publishing.

Heizer, J \& Render, B. (2009). "Operational Management $\quad\left(9^{\text {th }}\right.$ Edition)". Jakarta: Salemba Empat Press.

Hudayati, A, \& Tohirin, A. (2010). "Management of Zakah: Centralised vs Decentralised Approach", Seventh International Conference-The Tawhidi Epistemology: Zakat and Waqf Economy, Bangi.

Ibrahim, Sheriff. M. (2015). "The Role of Zakat in Establishing Social Welfare and Economic Sustainability", International Journal of Management and Commerce Innovations, 3(1), pp. 437-441.

Johari, Fuadah; Ali, Ahmad F. M \& Aziz, Muhammad R AB. (2015). "The Role of Zakat Distribution among Muallaf (New Convert) in Reducing Poverty in Selangor, Malaysia", Journal of Economic Policy Researches, 2(1), pp. 39-56.

Kantarci, Hasan B. (2015). "The Importance of Zakat in Struggle against Circle of Poverty and Income Redistribution", International Journal of Social, Behavioral, Educational, Economic, Business and Industrial Engineering, 9(1), pp. 351-354.

Lubis, Muharman; Yaacob, Nurul I; Omar, Yusoff \& Dahlan, Abdurrahman A. (2011). "Enhancement of Zakat Distribution Management System: Case Study in Malaysia", Kulliyyah of Information and Communication Technology (ICT).

Makridakis, Spyros; Wheelwright, Steven C \& McGee, Victor E. (1999). "Method and Application of Forecasting $2^{\text {nd }}$ Edition". Jakarta: Erlangga Press.
Makridakis, Spyros \& Wheelwright, Steven C. (2010). "Method and Application of Forecasting, $1^{\text {st }}$ Edition”. Tangerang: Binarupa Aksara Publisher.

Martiningtyas, N. (2004). "Module of STIKOM Statistics". STIKOM.

Mubarok, A \& Fanani, B. (2014). "Zakat Fund Collection (Potential, Realization and the Role of Zakat Institutions)", PERMANA, 5(2).

Parisi, Salman. Al. (2017). "Efficiency and Productivity of Zakat Institutions in Indonesia", ESENSI: Jurnal Bisnis dan Manajemen, 7(1), pp. 63-72.

Razak, Mohamad I Md; Omar, Roaimah; Ismail, Maymunah; Hamzah, Afzan S A \& Hashim, Mohd A. (2013). "Overview of Zakat Collection in Malaysia; Regional Analysis”, American International Journal of Contemporary Research, 3(8), pp. 140-148.

Riduwan. (2010). "Method and Thesis Composing Technique". Bandung: Alfabeta Press.

Saidi, M. (2008). "State Finance Law". Jakarta: Rajawali Press.

Shirazi, Nasim S \& Amin, Md F. (2009). "Poverty Elimination through Potential Zakat Collection in the OIC-Member Countries: Revisited", The Pakistan Development Review, 48(4), pp. 739-754.

Siddiqi, S. A. (1968). "Public Finance in Islam". Pakistan: Lahore.

Subagyo, P. (1986). "Forecasting Concept and Application". Yogyakarta: BPFE.

Supranto, J. (1984). "Quantitative Method for Planning”. Jakarta: Erlangga.

The National Board of Zakat. (2017). "Indonesian Zakat Outlook". Jakarta: Center of Strategic Studies, the National Board of Zakat.

Todaro, M. P \& Smith, S. C. (2012). "Economic Development $11^{\text {th }}$ Edition". England: Pearson Education. 
Ubaidillah, Sharifah. H Sy A \& Sallehuddin, Roselina. (2013).

"Forecasting Zakat Collection Using Artificial Neural Network", Proceedings of the 20th National Symposium on Mathematical Sciences AIP Conf. Proc. 1522, 196204.

Wei, W. (2006). "Time Series Analysis Univariate and Multivariate Methods". New York: Philadelphia Pearson.

Yaumidin, K. U. (2009). "Islamic Alternative: Comparative Study between Indonesia and Malaysia", Paper presented in The International Conference on Islamic Economics and Economics of the OIC Countries, Kuala Lumpur, 28-29 April.

Salman Al Parisi

IPB Business School

Bogor

Indonesia

salman.al.farisi.tazkia@gmail.com 
